Dikirim: 03-05-2021, Diterima: 18-11-2021, Terbit: 30-12-2021

\title{
Sejarah Perkembangan Pendidikan Indonesia Pada Masa Penjajahan Jepang
}

\author{
Suci Ramadhani \\ Universitas Sriwijaya \\ sucirdhni1811@gmail.com
}

\begin{abstract}
Abstrak
Jepang merupakan salah satu negara Asia yang pernah menjajah Indonesia. Pada zaman penjajahan Jepang, kebijakan pendidikan yang diterapkan memiliki perbedaan. Tujuan penelitian ini adalah untuk mengetahui sistem sistem pendidikan yang diterapkan pemerintahan Jepang di Indonesia. Adapun metode yang digunakan pada penelitian ini yaitu metode sejarah, melalui tahapan yaitu; heuristik, kritik, interpretasi, dan historiografi. Hasil penelitian ini menunjukkan bahwa sejarah perkembangan pendidikan Indonesia pada zaman penjajahan Jepang tidak banyak diketahui oleh masyarakat umum secara lebih jelas. Masyarakat beranggapan bahwa pendidikan pada zaman penjajahan Jepang ini sangat buruk. Jika dilihat dari sisi pendidikan kala itu memang sangat buruk sedangkan jika dilihat dari sisi lain hal itu memiliki dampak positif bagi Indonesia. Hal ini dapat dilihat dari penghapusan sistem golongan (kasta) yang membuat masyarakat golongan menengah ke bawah bisa bersekolah.
\end{abstract}

Kata Kunci: Sejarah, Pendidikan Indonesia, Penjajahan Jepang

\begin{abstract}
Japan is one of the Asian countries that once colonized Indonesia. During the Japanese colonial era, the educational policies applied were different. The purpose of this study was to determine the education system implemented by the Japanese government in Indonesia. The method used in this research is the historical method, through the stages, namely; heuristics, criticism, interpretation, and historiography. The results of this study indicate that the history of the development of Indonesian education during the Japanese colonial era was not widely known by the general public more clearly. People think that education during the Japanese colonial era was very bad. When viewed from the side of education at that time it was very bad, while if viewed from the other side it had a positive impact on Indonesia. This can be seen from the abolition of the class system (caste) which allows the lower middle class to go to school.
\end{abstract}

Keywords: History, Indonesian Education, Japanese Colonization

Jurnal Humanitas is licensed under a Creative Commons AttributionShareAlike 4.0 International License. 


\section{Pendahuluan}

Pada Januari 1942 melalui Ambon, Jepang mendarat dan memasuki Indonesia. Masuknya Jepang ke Indonesia tidak dengan mudah atau langsung masuk tanpa perlawanan. Sebab pada saat itu KNIL (tentara Hindia Belanda) telah berusaha menghalangi masuknya Jepang ke Indonesia, tetapi usaha mereka tidak membuahkan hasil dikarenakan kekuatan Jepang tidak terkalahkan (Yasmis, 2007). Setelah itu, satu persatu wilayah Indonesia berhasil diambil alih oleh Jepang. Sehingga pada tanggal 8 Maret 1942 pasukan Belanda menyerah kepada Jepang melalui penyerahan tidak bersyarat. Dengan hal ini, maka berakhirlah masa penjajaan Belanda dan memasuki masa pendudukan atau penjajahan Jepang di Indonesia.

Pengalihan kekuasaan Belanda ke kekuasaan Jepang disambut gembira oleh rakyat Indonesia. Sehingga muncul sebuah harapan atau keinginan baru dari masyarakat Indonesia untuk melepaskan diri dari tali jeratan penjajahan dan keinginan menjadi sebuah negara merdeka. Sedangkan di sisi lain Jepang terus menerus melakukan propaganda-propagana untuk menarik minat dan kepercayaan masyarakat Indonesia serta mempertahankan kedudukannya.

Bergantinya kependudukan Belanda menjadi kependudukan Jepang menimbulkan sebuah peralihan drastis. Hal ini dapat dilihat dari banyaknya sistem yang berganti dan dihapuskan, seperti salah satunya penghapusan sistem golongan (kasta) yang membuat masyarakat golongan menengah ke bawah bisa bersekolah. Selanjutnya, Jepang juga merubah dan menetapkan berbagai kebijakan dan peraturan. Untuk mewadahi semua kebijakan atau perubahan terhadap pendidikan Indonesia, Jepang mendirikan empat tingkat pendidikan untuk siswa dan beberapa jenis sekolah untuk guru yang tersebar di berbagai kota di Indonesia.

Namun, bagai pisau bermata dua Jepang tidak menduduki hanya untuk melepaskan Indonesia dari penjajahan Belanda dan membenahi sistem pendidikan. Hal ini dikarenakan mereka memiliki maksud yang tersembunyi yang pada akhirrnya hanya menyulitkan Indonesia khususnya di bidang pendidikan. Sehingga, bagai pinang dibelah dua, pendudukan Jepang di Indonesia tidak jauh dari masa pendudukan Belanda dan bahkan membuat rakyat lebih menderita.

Beberapa penelitian tentang sistem pendidikan pada zaman Jepang sudah dilakukan diantaranya penelitian Abbas (2018) tentang pendidikan di Indonesia pada masa Jepang. 
Kemudian ada penelitian Wahyuni (2015) tentang kurikulum dari masa ke masa, penelitian Rohman (2018) tentang kebijakan pendidikan Islam masa penjajahan Jepang, dan penelitian Muslimin \& Hudaidah (2021) tentang pendidikan Indonesia pada masa pendudukan Jepang. Penelitian ini melengkapi penelitian tersebut di atas sebagai wacana dalam melihat pola dan perkembangan pendidikan pada masa Jepang menjajah Indonesia.

Permasalahan dalam penelitian ini adalah bagaimana latar belakang masuknya Jepang ke Indonesia, perubahan dan penetapan sistem, kebijakan dan peraturan pendidikan indinesia serta kekurangan atau kelemahan dari sistem yang diterapkan Jepang untuk pendidikan Indonesia? Tujuan penelitian ini untuk mengetahui sistem pendidikan yang diterapkan pemerintahan Jepang. Oleh karena itu, penelitian ini menjelaskan lebih lanjut mengenai sejarah perkembangan pendidikan Indonesia pada masa penjajahan Jepang sebagai bagian tak terpisahkan dari sejarah pendidikan di Indonesia. Dalam konteks inilah urgensi penelitian ini penting untuk dipublikasikan.

\section{Metode Penelitian}

Penelitian ini menggunakan metode metode sejarah dengan proses tahapan kerjanya meliputi, heuristik, kritik, interpretasi, dan historiografi (Kuntowijoyo, 2015, Sjamsuddin, 2017). Data dikumpulkan berasal dari sumber-sumber pendidikan pada masa penjajahan Jepang. Data yang telah diperoleh kemudian dikritik untuk mengetahui apakah data tersebut dapat dipercaya dan cocok dengan tujuan penelitian serta mengecek kejelasan atau kualitas dari otentitas data tersebut. Interpretasi atau penafsiran sumber dari data yang telah dinyatakan lulus pada proses sebelumnya dilakukan agar fakta yang ada dapat memiliki makna sejarah yang utuh. Terakhir, historiografi dilakukan untuk menjelaskan seluruh peristiwa sejarah secara untuk yang mengandung unsur kronologis sebagai ciri khas dalam penelitian sejarah. Mengetahui secara sistematis sejarah perkembangan pendidikan Indonesia pada masa penjajahan Jepang.

\section{Pembahasan}

\section{Kedatangan Jepang di Indonesia}

Pertengahan tahun 1941 Amerika Serikat melacarkan embargo minyak bumi terhadap Jepang. Artinya, Amerika mengeluarkan pelarangan perniagaan dan perdagangan minyak bumi terhadap Jepang. Pelarangan perniagaan dan perdagangan yang dikeluarkan Amerika 
ini bertujuan untuk memperlemah kekuatan militer Jepang (Beasley, 2004: 319). Sedangkan Jepang sangat membutuhkan minyak bumi untuk industri dan keperluan perang. Perekonomian Jepang yang memburuk mengakibatkan masyarakatnya kesulitan untuk mendapatkan bahan makanan. Sebab sebagian besar makanan dikirim untuk dijadikan perbekalan para tentara di medan perang, maka distribusi makanan dari pemerintah terhadap rakyat kecil menjadi tersendat (Udiyani, 2013). Akhirnya, pada tanggal 8 Desember 1941 Jepang mengebom Pearl Harbour yang merupakan pangkalan terbesar Angkatan Laut Amerika di Pasifik. Akibat penyerangan yang berhasil menghancurkan pertahanan militer Amerika Serikat ini, yaitu meletusnya suatu Perang Pasifik. Selain pangkalan laut Amerika Serikat, serangan Jepang diarahkan ke Filipina dan kemudian serangan Jepang juga diarahkan ke Indonesia dengan tujuan untuk mendapatkan cadangan logistik dan bahan industri perang seperti minyak bumi, timah dan aluminium. Hal ini dikarenakan, selama perang Pasifik, persediaan minyak di Indonesia diperkirakan dapat mencukupi kebutuhan Jepang.

Pasca serangan Pearl Harbour pada Desember 1941, akhirnya pada awal tahun 1942 atau lebih tepatnya Januari 1942 Jepang mendarat dan memasuki Indonesia melalui Ambon (Indrayani \& Artono, 2016: 255). Namun, Jepang tidak masuk ke Indonesia dengan mudahnya begitu saja karena pada saat itu KNIL (tentara Hindia Belanda) dan pasukan Australia berusaha menghalangi. Namun, kekuatan Jepang tidak terkalahkan. Jepang kemudian berhasil menguasai seluruh kepulauan Maluku. Selajutnya Jepang juga menguasai Tarakan dan Balikpapan-Kalimantan Timur, kemudian masuk ke Pontianak dan menyerang pulau Sumatera.

Pada februari 1942 Jepang mulai menyerang pulau Jawa yang merupakan pusat pemerintahan Hindia Belanda. Untuk menhadapi Jepang blok sekutu yang terdiri Belanda, Amerika Serikat, Inggris, dan Australian membentuk komando gabungan ABDACOM, yaitu American-British-Dutch-Australian Command yang bermarkas di Lembang. Lalu pada tanggal 1 Maret 1942 pasukan Jepang mendarat di Jawa, yaitu terjadi di tiga tempat berbeda seperti Banten, Indramayu dan Bojonegoro. Pendaratan Jepang ini tidak terduga oleh Belanda, sehingga dengan cepat pasukan Jepang menyerbu pusat-pusat kekuatan Belanda.

Selanjutnya, pada 5 Maret 1942 kota Batavia sebagai pusat Pemerintahan Belanda berhasil jatuh ketangan Jepang dan diikuti kota-kota lainnya yang dengan mudah dikuasai oleh Jepang hampir tanpa perlawanan. Akhirnya, tiga hari setelah kota Batavia jatuh ke 
tangan Jepang atau lebih tepatnya pada tanggal 8 maret 1942 pasukan Belanda menyerah kepada Jepang melalui penyerahan tidak bersyarat yang ditanda tangani oleh Jendrak Ter Poorten sebagai wakil dari Beladan dan jendral Imamura sebagai wakil dari pasukan Jepang. Hal ini sejalan dengan Yasmin (2007:24) yang menyatakan bahwa penyerahan tanpa syarat yang dilakukan oleh Belanda pada tanggal 8 Maret 1942 dari Jenderal Terpoorten kepada Hitoshi Imamura di Kalijati Jawa Barat menyebabkan berakhirnya kekuasaan Belanda di Indonesia. Selanjutnya, Indonesia memasuki sejarah babak baru, yaitu masa penjajahan Jepang. Penandatanganan yang dilakukan di Kalijati kota Subang ini membuat peristiwa tersebut disebut dengan Kapitulasi Kalijati. Dengan demikian berakhirlah masa penjajahan Belanda di Indonesia, selanjutnya Indonesia berada di bawah kependudukan Jepang.

Pada awalnya, kedatangan Jepang ke Indonesia disambut dengan senang hati oleh rakyat Indonesia. Hal ini sejalan dengan yang diungkapkan Rohman (2018: 17) bahwa rakyat Indonesia menyambut kedatangan Jepang ke Nusantara dengan terbuka. Selain itu, penyambutan yang dilakukan oleh rakyat Indonesia terhadap Jepang dapat dilihat dari banyaknya orang mengucapkan "banzai" yang artinya "selamat datang". Sambutan positif rakyat Indonesia ini merupakan wujud rasa syukur dan legah rakyat dari terbebesnya belenggu penjajahan kolonial Belanda yang telah mengekung selama ratusan tahun. Menurut Indrayani dan Artono (2016) ekspresi kegembiraan pada wajah rakyat Indonesia merupakan bentuk harapan mereka untuk lepas dari penindasan Kolonial Belanda setelah sekian lama dijajah oleh Belanda.

\section{Pendidikan di Indonesia Pada Masa Jepang}

Bergantinya kependudukan Belanda menjadi kependudukan Jepang menimbulkan sebuah peralihan drastis dalam berbagai bidang termasuk pada bidang pendidikan. Hal ini dapat dilihat dari banyaknya sistem ataupun peraturan yang berganti dan dihapuskan. Adapun sistem pendidikan yang diterapkan Jepang di Indonesia yaitu, mengakomodasi kurikulum berorientasi lokal. Hal ini diakibatkan kegagalan Jepang dalam mengaplikasikan Nipponize (Jepangisasi) pendidikan di Manchuria. Sehingga, di Indonesia Jepang menerapkan perpaduan antara kurikulum lokal dengan kurikulum Jepang.

Penghapusan mekanisme pendidikan yang ditetapkan oleh Belanda kemudian digantikan oleh buatan Jepang, mengharuskan pemerintah Jepang untuk menata ulang 
pendidikan di Indonesia. Untuk itu, pemerintah Jepang mengeluarkan berbagai kebijakan. Kebijakan-kebijakan tersebut yaitu sebagai berikut.

a. Format pendidikan mengakomodasi kurikulum berorientasi lokal. Seperti yang telah dijesalkan sebelumnya bahwa akibatkan kegagalan Jepang dalam mengaplikasikan Nipponize (Jepangisasi) pendidikan di Manchuria. Di Indonesia, Jepang menerapkan perpaduan antara kurikulum lokal dengan kurikulum Jepang.

b. Mengambil tenaga pribumi, yaitu dengan merekrut Ki Hajar Dewantara sebagai penasehat bidang pendidikan. Pengambilan tenaga pribumi ini bertujuan untuk menarik simpati dan dukungan rakyat Indonesia.

c. Melatih guru-guru agar memiliki keseragaman pengertian tentang maksud dan tujuan dari pemerintahannya. Pada awal pergantian sistem pendidikan ini, tidak banyak guru yang mengerti akan maksud, tujuan, dan pemahaman materi pendidikan buatan Jepang. Untuk itu diadakan sebuah pelatihan untuk para guru. Adapun materi pokok dalam latihan tersebut antara lain: 1) Nippon Seisyin, yaitu latihan semangat Jepang dan kemiliteran; 2) indoktrinasi ideologi Hakko Ichiu; 3) Ilmu bumi dengan perspektif geopolitis; 4) Bahasa, sejarah dan adat istiadat Jepang; serta 5) Nyanyian dan olahraga Jepang.

d. Sekolah-sekolah berbahasa Belanda diinstruksi untuk segerah dihapus atau ditutup, dan terjadi pelarangan materi tentang Belanda dan Bahasa-bahasa Eropa lainnya. Sehingga dengan hal ini Peranakan China dipaksa untuk kembali ke sekolah-sekolah berbahasa Mandarin di bawah koordinasi Hua-Chino Tsung Hui, yang berimplikasi padda adanya proses resinification (penyadaran dan penegasan identitas sebagai keturunan bangsa China).

e. pemerintah Jepang sering mengadakan junjungan dan memberi bantuan ke pondok pesantren. Kunjungan ke pondok pesantren dan memberikan bantuan kepada lembaga pendidikan Islam tersebut terjadi hamper setiap minggu. Menurut Maksum (1999) (dalam Sabarudin, 2015) hubungan dengan para pemimpin pondok semakin dipererat agar Jepang kedudukannya semakin kuat dari pengaruh kiai tersebut.

f. Mengizinkan pembentukan barisan Hizbullah yang mengajarkan latihan dasar semikemiliteran bagi pemuda islam di bawah pimpinan K.H. Zainal Arifin; Mengizinkan berdirinya Sekolah Tinggi Isalam di Jakarta di bawah asuhan K.H. Wahid Hasyim, Kahar Muzakkir dan Bung Hatta. 
g. Di izinkannya ulama dan pemimpin nasionalis membentuk barisan Pembela Tanah Air (PETA) yang bakal menjadi cikal-bakal TNI di zaman kemerdekaan

h. Di izinkannya Majelis Islam A'la Indonesia (MIAI) terus beroperasi, sekalipun kemudian dibubarkan dan diganti dengan Majelis Syuro Musimin Indonesia (Masyumi) yang menyertakan dua ormas besar islam, Muhammadiyah dan NU.

i. Kantor Voor Islamistische Zaken pada masa Belanda yang dipimpin oleh kaum orientalis dirubah Jepang menjadi Sumubi. Di mana untuk pimpinannya diserahkan kepada rakyat Indonesia sehingga salah satu tokoh Islam yang menjadi pimpinannya, yakni K.H. Hasyim Asy'ari. Selain itu, organisasi Islam yang sudah ada di zaman Belanda dan diurus oleh Belanda kemudian diberikan hak penuh oleh Jepang kepada umat Islam untuk mengurus organisasi Islam tersebut, yang secara langsung diserahkan kepada K.H. Hasyim Asy'ari (Aslan dan Hifza 2019).

Setelah mengeluarkan berbagai kebijakan terhadap pendidikan di Indonesia, selanjutnya Jepang mewajibkan para siswa untuk melakukan beberapa aktivitas. Aktivitas tersebut yaitu sebagai berikut:

1. Menyanyikan lagu kebangsaan Jepang, Kimigayo setiap pagi.

2. Mengibarkan bendera Jepang dan menghormat Kaisar Jepang setiap pagi.

3. Setiap pagi harus melakukan Dai Toa, bersumpah setia kepada cita-cita Asia Raya.

4. Setiap pagi diwajibkan melakukan Taiso, senam Jepang .

5. Melakukan latihan-latihan fisik dan militer.

6. Menjadikan Bahasa Indonesia sebagai pengantar dalam pendidikan. Sedangkan bahasa yang wajib diajarkan hanya Bahasa Jepang, bahasa Belanda, Inggris, dan bahasa-bahasa Eropa lainnya dilarang untuk digunakan dan diajarkan.

Hilangnya kekuasaan Belanda diikuti tumbangnya sistem pendidikan yang didirikan oleh Belanda menyebabkan sekolah-sekolah dengan sistem pembedaan golongan ikut lenyap dan berganti dengan sistem yang merata tanpa memandang golongan (kasta). Sehingga dengan ini masyarakat golongan bawah bisa bersekolah. Hal ini dapat dilihat pada masa Belanda, yaitu rakyat yang dapat merasakan pendidikan formal hanya rakyat pribumi untuk kalangan atas, sementara rakyat kecil tidak bisa memiliki kesempatan. Sedangkan untuk mengenyam pendidikan, Jepang mulai menerapkan pola pendidikan semua rakyat dan lapisan. Hal ini memungkinkan rakyat golongan menengah kebawah berhak untuk mengenyam pendidikan formal yang dibuat oleh Jepang tanpa membedakan golongan kasta 
(Fadli dan Kumalasari, 2019). Dengan ini kebijakan yang diterapkan pernerintah Jepang di bidang pendidikan adalah menghilangkan diskriminasi dalam mengenyam pendidikan.

Adanya kebijakan penghilangan diskriminasi yang ditetapkan Jepang menjadikan jumlah murid bertambah. Untuk itu diperlukan lembaga pendidikan mengurusnya. Namun, dengan runtuhnya kekuasaan atau kependudukan Belanda terhadap Indonesia, maka lembaga-lembaga pendidikan buatan Belanda ditutup. Sebagai gantinya Jepang mendirikan lembaga-lembaga pendidikan baru untuk para sisiwa dengan tingkatan dan mekanisme yang baru pula. Adapun tingkatan lembaga pendidikan yang disediakan pemerintah Jepang untuk siswa, yaitu sebagai berikut.

1. Pendidikan Dasar (Kokumin Gakkso/ Sekolah rakyat). Saat ini lebih dikenal dengan sekolah dasar yang lama jenjang pendidikan ini adalah 6 tahun. Sesuai dengan yang di terapkan sejak masa pendudukan Jepang.

2. Pendidikan Lanjutan yang terdiri dari Shoto Chu Gakko (Sekolah Menengah Pertama) dengan lama pendidikan selama 3 tahun dan Koto Chu Gakko (Sekolah Menengah Tinggi/ Atas) yang juga ditempuh dalam waktu 3 tahun.

3. Pendidikan Kejuruan. Sekolah yang setingkat SMA berfokus pada kemampuan kerja siswa atau hal praktek bukan pada hal akademik. Seperti dalam bidang-bidang pekerjaan pertukangan, pelayaran, pendidikan, teknik, dan pertanian. Sekolah ini ditujukan untuk pelajar yang ingin langsung bekerja tanpa masuk ke tingkat perguruan tinggi terlebih dahulu.

4. Perguruan Tinggi. Perguruan tinggi merupakan tingkatan tertinggi dalam jenjang pencarian ilmu yang dibentuk atau ditentukan oleh pemerintah Jepang.

Peralihan masa kependudukan Belanda ke masa kependudukan Jepang tidak hanya berimbas kepada sistem dan pada siswa saja. Paga guru sebagai tenaga pendidik juga memperoleh imbasnya. Belum lagi peralihan kekuasaan ini menyebabkan semua sekolah berbasis Belanda ditutup. Akibatnya, para guru terpaksa mengartikan segala buku catatan Belanda kedalam Bahasa Jepang dan Indonesia. Lalu, perubahan sekolah akademis menjadi sekolah vokasi. Kemudian pelarangan untuk membangun sekolah swasta yang mengakibatkan ditutupnya Taman Guru dan Tama Madya. Sehingga adanya penutupan sekolah-sekolah buatan Belanda membuat jumlah sekolah di Indonesia berkurang pesat, baik itu sekolah untuk siswa maupun sekolah untuk mendidik para guru semuanya mengalami pengurangan dan perubahan mekanisme. 
Berkurangnya jumlah sekolah ini menyebabkan jumlah guru juga berkurang dan kurang terdidik. Untuk mengatasi hal tersebut. Para guru yang yang harus mengajar di sekolah serta kurang terdidik mengenai sistem buatan Jepang akan diberi pelatihan. Jepang mengambil tenaga pendidik dari Indonesia yang diseleksi di tiap kabupaten. Setelah selesai penyeleksian, maka diadakan pelatihan di Jakarta. Setelah selesai maka kembali ke daerahnya masing-masing dan menjadi guru di sekolah yang terdapat di daerah tersebut (Khoiriyah, 2017). Guru yang mendapatkan pelatihan di Jakarta dengan waktu beberapa bulan, mendapatkan materi sesuai dengan kebijakan Jepang, yang nantinya akan diajarkan kepada masyarakat Indonesia di seluruh wilayah Indonesia. Maka dengan ini usaha penanaman Ideologi Hakko Ichiu melalui sekolah-sekolah dimulai dengan mengadakan pelatihan guru-guru. Guru-guru diberi tugas sebagai penyebar ideologi tersebut. Pelatihan yang berlangsung selama 3 bulan tersebut dirasa cukup untuk menjepangkan para guru (Wiranata, 2018). Selain itu, pemerintah Jepang mendirikan 3 jenis sekolah untuk mendidik para Guru, yaitu sebagai berikut:

a. Sekolah guru 2 tahun (Syoto Sihan Gakko)

b. Sekolah guru 4 tahun (Gotu Sihan Gakko)

c. Sekolah guru 6 tahun (Koto Sihan Gakko)

Selanjutnya pemerintah Jepang mendirikan Beberapa lembaga pendidikan untuk mendidika para guru. Lembaga pendidikan tersebut yaitu sebagai berikut:

a. SPG atau Sekolah Pendidikan Guru. Terdapat pada lima kota, yaitu Jakarta, Bandung, Yogyakarta, Surakarta, dan Blitar

b. SGMT atau Sekolah Guru Menengah Tinggi. SGMT merupakan sekolah jenjang menengah dengan tingkatan di atas SPG. Lama studinya yaitu 4 tahun bagi para lulusan SMP dan SGB, dan 1 tahun untuk lulusan SMA. Sekolah ini hanya menerima siswa lakilaki dan terdapat di Jakarta.

c. SGKP atau Sekolah Guru Kepandaian Putri. SGKP dikhususkan bagi anak perempuan. Lama studi sekolah ini yaitu 4 tahun.

Penetapan dan perubahan kebijakan, peratutan serta sistem terhadap pendidikan Indonesia oleh pemerintah Jepang ini memiliki tujuan dan fungsinya tersendiri bagi pemerintah Jepang. Adapun tujuan dari pendidikan yang dibentuk oleh pemerintahan Jepang terhadap pendidikan di Indonesia yaitu untuk menarika simpati pribumi agar mau membantu dan membela serta memenangkan Jepang dalam perannya di Perang Dunia. Sementara itu, 
fungsi pendidikan yang dibentuk Jepang terhadap Pendidikan di Indonesia yaitu sebagai penyedia tenaga cuma-cuma (Romusha) dan prajirit-prajurit untuk membantu peperangan bagi kepentingan Jepang. Hal ini dikarenakan seperti yang telah dijelaskan sebelumnya bahwa saat Jepang menjajah Indonesia mereka sedang mengalami peperangan melawan sekutu.

Bersamaan dengan perubahan, pergantian dan perbaikan yang dilakukan Jepang untuk memajukan pendidikan di Indonesia. Bagaikan pisai bermata dua, Jepang memiliki maksud lain dibalik niat baiknya yang diketahui rakyat. Jepang terus melakukan berbagai Propaganda untuk menggerakkan dukungan. Rakyat Indonesia didoktrin bahwa kedatangan Jepang ke Indonesia adalah untuk membebaskan rakyat dari penjajahan serta dapat memajukan kesejahteraan. Berbagai propaganda yang dilakukan Jepang yaitu sebagai berikut.

a. Propaganda melalui siaran radio.

Lagu Indonesia Raya diperdengarkan disamping lagu kebangsaan Jepang, Kimigayo. Jepang juga melakukan Propaganda mengenai produk-produk buatan Jepang di radio. Adapun menurut Rohman (2018: 21) propaganda melalui radio bertujuan untuk menyebarkan informasi pidato pemerintah Jepang, pendidikan dan sarana atau media belajar untuk rakyat mengenai berbagai topik termasuk salah satunya mengenai pendidikan. Penyebaran informasi pidato ini bisa saja disampaikan secara langsung oleh pemerintah Jepang ataupun melalui tokoh-tokoh nasionalis terkenal, seperti salah satunya Ir. Soekarno. b. Pengibaran Bendera merah putih diperbolehkan

Pengibaran bendera merah putih ini berdampingan dengan bendera Jepang. Bersamaan dengan bendara nasional Jepang pengibaran bendera kebangsaan Indonesia Merah Putih diizinkan dikibarkan. Termasuk bersamaan dengan lagu kebangsaan Jepang "Kimigayo" lagu Indonesia Raya boleh dinyanyikan. Sehingga rakyat betul-betul percaya bahwa Jepang ingin memerdekan Indonesia dengan slogan "Indonesia-Jepang sama-sama" (Sahajuddin, 2019). Namun, hal ini juga harus dimaknai ganda bahwa kemerdekaan hanyalah sebuah ilusi jika Jepang menang dalam perang Pasifik, atau ada kemungkinan kemerdekaan Indonesia akan diraih atas bantuan Jepang.

c. Program Pan-Asia.

Propaganda juga dilakukan oleh Jepang melalui program Pan-Asia dimana Jepang akan memajukan dan menyatukan seluruh rakyat Asia. Berdasarkan program tersebut Jepang 
menunjukkan bahwa mereka memiliki sebuat cita-cita besar, yaitu menjadi pemimpin Asia Timur Raya (Abbas, 2018:64). Sehingga gerakan "Tiga A" dengan semboyan Jepang Cahaya Asia, Jepang Pelindung Asia dan Jepang Pemimpin Asia diluncurkan, untuk meneguhkan propaganda ini. Propaganda ini menimbulkan atau membuat kampanye slogan yang dimulai sejak mei 1942 yang pelaksanaannya dikerahkan kepada bangsa Indonesia, yaitu Mr. Syamsudin (Rohman, 2018:17).

Oleh sebab itu, sistem pendidikan Jepang untuk mencerdaskan bangsa Indonesia tidak bertahan lama, yaitu hanya berjalan selama satu tahun setengah. Kemudian pada bulan September 1943, Jepang membuat kebijakan baru dengan misi Nipponisasi yang mana Jepang mengajarkan kepada rakyat Indonesia tentang latihan militer (Kawamura, 2004). Latihan-latihan militer untuk masyarakat Indonesia yang diajarkan Jepang, diadakan di Jakarta selama 3 bulan. Latihan tersebut mencakup: Pertama, mengumpulkan pasir dan batu; Kedua, membersihkan asrama Jepang dan bengkel. Ketiga, untuk persediaan makanan Jepang, rakyat diharuskan menanam umbi-umbian dan sayur-sayuran di pekarangan sekolah. Keempat, diharuskan mempunyai semangat perang dan mengucapkan sumpah setia kepada kaisar Jepang setiap pagi yang mana pengucapan tersebut menggunakan bahasa Jepang (Ramayulis, 2011: 340). Adapun pengucapan menggunakan bahasa Jepang ini tanpa diketahui oleh yang mengucapkan. Selanjutnya agar sejalan dengan ideologi Jepang, para pemimpin pondok dan masyarakat yang berpengaruh diberikan pelatihan selama sebulan di Jakarta (Rohman, 2018).

Selain itu, pada masa pendudukan Jepang masalah pendidikan tidak diperhatikan. Hal ini berkebalikan dengan masa Hindia Belanda yang sangat memperhatikan pendidikan. Adapun bukti dari hal ini yaitu terjadi penurunan jumlah sekolah yang diakibatkan oleh penutupan sekolah-sekolah berbasis Belanda. Penurunan jumlah sekolah ini yaitu, jumlah sekolah dasar menurun, yang sebelumnya berjumlah 21.500 manjadi 13.500, jumlah sekolah lanjutan menjadi 20 dari 850 dan jumlah perguruan Tinggi/ Fakultas hanya terdiri dari 4 buah. Sehingga tingkat intelektualitas rakyat menurun akibat dari pendidikan bagi rakyat yang kurang diperhatikan ini. Selain itu, walaupun usaha untuk memberantas buta huruf telah dikerahkan, angka buta huruf masih tinggi sekali. Maka dengan ini dapat dikatakan bahwa sistem pengajaran dan struktur kurikulum hanya ditujukan kepada keperluan Perang Asia Timur Raya (Perdana, 2011) 
Dengan hal ini, dalam sejarah bangsa Indonesia masa pendudukan Jepang di Indonesia merupakan salah satu periode paling singkat tetapi amat kelam salah satunya dapat dilihat pada bidang pendidikan. Namun, di dalam benak rakyat Indonesia Jepang merupakan pembebas dari belenggu penjajahan Belanda, pada awalnya. Kemudian dalam pendidikan Indonesia penerapan slogan 3A (Jepang Cahaya Asia, Jepang Pelindung Asia, Jepang Pemimpin Asia) merupakan propaganda Jepang sangat jelas. Tidak hanya itu, bangsa Indonesia juga dibuat percaya oleh Jepang mengklaim diri sebagai "saudara tua" bangsa Indonesia (Muhajir, et. al, 2021).

Pada akhirnya, sekarang tidak dapat dihindari bahwa akan banyak masyarakan sekarang yang beranggapan bahwa pendidikan Indonesia pada masa penjajahan Jepang sangatlah buruk. Hal ini terlihat dari perubahan dan penurunan yang terjadi. Namun, disamping itu Jepang juga memberikan dampak positif bagi pendidikan Indonesia, seperti dengan melepaskan Indonesia dari belenggu kekuasaan Belanda, Jepang telah merubah sistem dan kebijakan pendidikan Indonesia buatan Belanda yang sangat tidak menguntungkan masyarakat golongan bawah. Selain itu, Jepang juga telah membukakan mata dan memberikan dorongan (dengan kekejamannya) bagi masyarakat Indonesia untuk terus berjuang dan berambisi agar dapat merdeka seutuhnya.

\section{Kesimpulan}

Kesimpulan dari uraian diatas yaitu sejarah perkembangan pendidikan Indonesia pada masa penjajahan Jepang dimulai sejak menyerahnya Belanda kepada Jepang melalui penyerahan tidak bersyarat pada tanggal 8 Maret 1942 pendidikan Indonesia mengalami perubahan sistem yang sangat drastis dari sistem pendidikan yang dibuat oleh Belanda. Pada awalnya Jepang menutup semua sekolah berasis belanda, membuat sekolah-sekolah baru dan merubah serta menetapkan berbagai kebijakan dan peraturan. Selain itu, menghapuskan sistem kasta (golongan) sehingga rakyat yang berada pada golongan bawah bisa bersekolah. Namun, pada akhirnya perubahan dari sistem, kebijakan dan peraturan ini malah mempersulit rakyat untuk bisa bersekolah. Tidak hanya rakyat pada guru yang terbiasa menggunakan sistem pandidikan yang di buat Belanda dibuat bodoh oleh sistem yang baru dan tidak mereka pahami. Selain itu, dampakyang amat terasa yaitu berkurangnya jumlah sekolah akbat dari penutupan sekolah Belanda yang di lakukan jepang. Oleh karena itu, tidak dapat dihindari bahwa akan banyak masyarakan sekarang yang beranggapan bahwa 
pendidikan Indonesia pada masa penjajahan Jepang sangatlah buruk. Hal ini dikarenakan memang benar bahwa pada masa penjajahan Jepang pendidikan Indonesia mengalami penurunan dan sangat buruk yang dapat dilihat dari hasil dan pemabahasan penelitia diatas. Namun, jika dilihat dari sisi lain Jepang juga memberikan dampak baik (dampak positif) bagi pendidikan Indonesia.

\section{Daftar Rujukan}

Abbas, A. (2018). Pendidikan di Indonesia pada Masa Jepang. Ash-Shahaba: Jurnal Pendidikan dan Studi Islam, 4(1), 62-75.

Aslan, A., \& Hifza, H. (2019). Pendidikan Islam Masa Penjajahan Jepang di Sambas, Indonesia. EDUKASIA ISLAMIKA Jurnal Pendidikan Islam, 4(2), 171-188.

Beasley, W. G. (2004). Pengalaman Jepang: Sejarah Singkat Jepang. Jakarta: Yayasan Obor Indonesia.

Fadli, M. R., \& Kumalasari, D. (2019). Sistem ketatanegaraan Indonesia pada Masa Pendudukan Jepang. Sejarah dan Budaya: Jurnal Sejarah, Budaya, dan Pengajarannya, 13(2), 189-205.

Indrayani, Y., \& Artono. (2016). Propaganda Jepang Dalam Majalah Soeara Moeslimin Indonesia Tahun 1944-1945. AVATARA, e-Journal Pendidikan Sejarah, 4(2), 254268.

Kawamura, C. (2004). Pendidikan Sekolah Rakyat di Jawa Pada Masa Pendudukan Jepang dari Perspektif Buku Pelajaran. Lembaran Sejarah, 7(1), 155-172.

Khoiriyah, R. (2017). Revitalisasi Pendidikan Islam dalam Perspektif Kiai Hasyim Asy’ari. Jurnal Islam Nusantara, 01(02), 156-170.

Muhajir, A., Sumantri, P., \& Gultom, A. Z. (2021). Memori Sejarah dan Warisan Pendudukan Jepang di Sumatera Timur sebagai Potensi Wisata Sejarah. MUKADIMAH: Jurnal Pendidikan, Sejarah, dan Ilmu-ilmu Sosial, 5(1), 149-158.

Muslimin, Y., \& Hudaidah, H. (2021). Pendidikan Indonesia pada Masa Pendudukan Jepang. Journal of Practice Learning and Educational Development, 1(3), 1-5.

Perdana, N. A., \& Magelang, S. M. A. N. (2011). Pengaruh Pendudukan Jepang Terhadap Masyarakat Magelang 1942-1945. Paramita: Historical Studies Journal, 20(2). 143157.

Rohman, M. (2018). Kebijakan Pendidikan Islam Masa Penjajahan Jepang. Al-Hikmah: Jurnal Pendidikan Agama Islam, 02(01), 15-33.

Sabarudin, M. (2015). Pola dan Kebijakan Pendidikan Islam Masa Awal dan Sebelum Kemerdekaan. Jurnal Tarbiya, 1(1), 139-174.

Sahajuddin, S. (2019). Propaganda dan Akibatnya Pada Masa Pendudukan Jepang di Enrekang (1942-1945). Walasuji : Jurnal Sejarah dan Budaya, 10(2), 185-201. 
Udiyani, I. A. D. (2013). Dampak Negatif Invasi Militer Jepang Pada Zaman Shouwa Dalam Manga Madomowazeru Batafurai Karya Ogura Akane. HUMANIS: Journal of Arts and Humanities, 5(2), 1-8.

Wahyuni, F. (2015). Kurikulum dari Masa ke Masa (Telaah Atas Pentahapan Kurikulum Pendidikan di Indonesia). Al-Adabiya, 10(2), 231-242

Wiranata, P., Safitri, S., \& Sair, A. (2018). Perkembangan Pendidikan di Palembang pada Tahun 1942-1950 (Sumbangan Materi Pembelajaran Mata Kuliah Sejarah Pendidikan). Criksetra: Jurnal Pendidikan Sejarah, 7(1), .

Yasmis. (2007). Jepang dan Perjuangan Kemerdekaan Indonesia. Jurnal Sejarah Lontar, $4(2), 24-32$. 